\title{
A KÖNYVTÁRAK SZEREPE A DIGITÁLIS ÉS ELEKTRONIKUS TANANYAGOK ARCHIVÁLÁSÁBAN
}

\author{
Nagy Gyula \\ SZTE Klebelsberg Könyvtár - SZTE Neveléstudományi Doktori Iskola \\ gyula.nagy@ek.szte.hu \\ ORCID: 0000-0002-8391-2851
}

DOI: 10.31915/NWS.2018.13

The role of libraries in archiving open educational resources The spread of digital and electronic learning materials is ongoing at various levels of the education system, but at the same time the curriculum developers and librarians have not clarified many important issues yet. One of the unanswered questions is the ensuring of the long-term sustainability, retrievability and preservation of digitized and born-digital curricula. It intensifies the problems that generic and unambiguous standards for the production, supply and preservation of e-learning materials do not exist. Frameworks for the dynamic and interactive use of e-learning materials and MOOC courses vary from year to year: new ones are born, and stable platforms are eliminated. In this ever-changing, chaotic environment, the library could be a firm basis as a true memory institution, playing a leading role as the developer of long-term archiving solutions of digital educational materials. A brief international outlook shows some good practices from the OER (Open Educational Resources) repository world. Moreover, our developed solution provides the integration of institutional teaching materials through widely-used repository systems.

Keywords: e-learning, digital curriculum, archiving, repository, open educational resources

\section{Bevezetés}

A digitális és elektronikus tananyagok térhódítása az oktatási rendszer különböző szintjein folyamatosan zajlik, ugyanakkor eddig a tananyagfejlesztő és a könyvtáros szakma is adós maradt számos fontos kérdés tisztázásával. Az egyik megválaszolatlan kérdés a digitalizált illetve a digitálisan előállított tananyagok hosszú távú fenntarthatóságának, visszakereshetőségének és megőrzésének biztosítása. Ennek a speciális, mind technikailag, mind tartalmilag rendkívül szerteágazó müfajt képviselö, erősen a szürke irodalomba hajló dokumentumtípusnak az archiválása számtalan megoldandó, elvi és gyakorlati (pl. menedzsment, informatika) problémát felvet, amelyek egy része egyébként erősen emlékeztet a hazánkban éppen bimbózó szakaszban lévő internetarchiválás által felvetettekre.

Bővíti a problémateret, hogy az elektronikus tananyagok előállítása, szolgáltatása, megőrzése kapcsán generálisan és egyértelműen alkalmazható iparági sztenderdek egyelöre még kevéssé kristályosodtak ki. Az e-learning oktatási anyagok és a különféle MOOC-kurzusok dinamikus és interaktív lejátszását lehetővé tevő keretrendszerek évről évre változnak: újak születnek, stabilnak hitt platformok pedig megszünnek. Ebben a folyamatosan változó, kissé kaotikus környezetben a könyvtár lehet az a biztos pont, amely igazi memóriaintézményként viselkedve vezető szerepet játszhat a digitális oktatási anyagok hosszú távú tárolását lehetővé tévő archiválási megoldások kidolgozásában. Nemzetközi kitekintésünkben röviden bemutatunk néhány jó gyakorlatot az OER (Open Educational Resources) repozitóriumok világából. 


\section{NETWORKSHOP 2018}

Az általunk kidolgozott módszer a felsőoktatási- és szakkönyvtárak által közelmúltban kiépített és üzemeltetett, mára széles körben müködő repozitóriumrendszerek esetében alkalmazott megoldások kiterjesztésével kísérli meg az intézményi oktatási anyagok integrálását ennek a speciális dokumentumtípusnak a begyűjtésével, rendszerbe szervezésével, raktározásával és a hosszú távú biztonságos megőrzés céljával.

\section{Elméleti háttér}

Az elmúlt években a könyvtárak jövője és ezzel együtt megújuló szerepeik jó néhány szakmai fórumnak és publikációnak szolgáltak témául. A teljesség igénye nélkül, ilyen volt például „A jövő könyvtára felé...” webinárium-sorozat ${ }^{1}$ a Miskolci Egyetem Könyvtár, Levéltár, Múzeum és a II. Rákóczi Ferenc Megyei és Városi Könyvtár szervezésében, de említhetnénk a Magyar Könyvtárosok Egyesülete által szervezett vándorgyülések különböző szekció-előadásait is, vagy jó néhányat az elmúlt évek Networkshopjain elhangzott elöadások közül. De ugyanebbe a tematikus sorba illeszkedik az MIT könyvtára által a tavalyelőtti év végén kiadott előzetes kutatási jelentés is a könyvtárak jövőjéröl.²

Az említett előadásokban, publikációkban a megújuló szerepek között eddig talán kevésbé hangsúlyosan jelent meg a nem hagyományos könyvtári dokumentumok archiválásának kérdése. A felsőoktatási könyvtárakban ennek speciális típusát jelentik (a szürke irodalom egyéb kategóriái mellett) a különféle tananyagok. Ugyanakkor a kérdés releváns megválaszolása egyre inkább akuttá válik, hiszen a digitális és elektronikus tananyagok térhódítása az oktatási rendszer különböző szintjein folyamatosan zajlik. Ennek ellenére mindeddig a tananyagfejlesztő és a könyvtáros szakma is adós maradt számos fontos kérdés tisztázásával. Az egyik megválaszolatlan kérdés a digitalizált illetve a digitálisan előállított tananyagok hosszú távú fenntarthatóságának, visszakereshetőségének és megőrzésének biztosítása.

Rohamosan haladunk a digitális szingularitás állapota felé, amikor minden valaha létező és folyamatosan keletkező (analóg és már digitális formában született) információs anyag (szöveg, kép, hang, mozgókép) elérhető lesz a hálózaton. ${ }^{3}$ Ez a változás már egy ideje együtt fejti ki hatását az oktatási ökoszisztéma teljes átalakulásával, amely az innovatív technológiák oktatásba való becsatornázásával rohamos léptekben fog elvezetni az oktatás teljes körü digitalizációjáig. ${ }^{4}$ Ezen hatások miatt megváltozó környezetre a könyvtáraknak reagálniuk szükséges, ezt általában el is várják tőlük a fenntartók és a felhasználók. Mivel kész, kikristályosodott megoldások egyelöre még nem nagyon léteznek ezen a területen, ezért a legtöbb esetben a lehetséges megoldási útvonalakat is nekik kell kimunkálniuk.

\footnotetext{
1 „A jövő könyvtára felé ...” — webináriumi sorozat. Il. Rákóczi Ferenc Megyei és Városi Könyvtár Miskolci Egyetem Könyvtár, Levéltár, Múzeum Miskolc, 2016-2018, Hozzáférés: 2018.05.30. http://digitalia.lib.pte.hu/books/a-jovo-konyvtara-fele-webinariumi-sorozat-2016-2018/htm/index.html

2 Nagy Gyula, Molnár Sándor, Kokas Károly. A könyvtárak jövőjéről - Reflexiók egy előzetes kutatási jelentés kapcsán. Tudományos és Müszaki Tájékoztatás, 64. 2. sz. (2017), 64-82.

$3 \quad$ Nagy Gyula. Megy-e a digitalizálás által a világ elébb? Avagy mi végre digitalizálunk? Információs Társadalom: társadalomtudományi folyóirat, 14. 3. sz. (2014), 44-52. Pap Dalma. Digitális környezet, mint a tanulás elsődleges közege. Opus et Educatio, 4. 1. sz. (2017), 53-61.
} 
A mostanában sürün emlegetett e-learning és MOOC-rendszerek térhódítása ugyan lényegi jelentőséggel bírnak ${ }^{5}$, de valójában csak egy kis szeletét jelentik az összképnek, az egész problématér jóval komplexebb. A napjainkban kézzelfogható módon tapasztalható trendek rövid időn belül elvezethetnek az oktatás világméretű online expanziójáig, egy ideális forgatókönyv szerint demokratizálva azt a mostani állapotokhoz képest.

A vázolt folyamat során nagy mennyiségben keletkező elektronikus tananyagok speciális, mind technikailag, mind tartalmilag rendkívül szerteágazó müfajt képviselő, erősen a szürke irodalomba hajló dokumentumtípust alkotnak. Archiválásuk számtalan megoldandó, elvi és gyakorlati (pl. menedzsment, informatika) problémát felvet, amelyek egy része egyébként erősen emlékeztet a hazánkban éppen bimbózó szakaszban lévő internetarchiválás által felvetettekre ${ }^{6}$, hiszen a legfőbb problémát általában a tananyagok internetről való nyomtalan eltűnése jelenti. Emellett a másik legsúlyosabb probléma a belső, intézmény felé való széles körü és egyenletes láthatóság biztosítása, amely az esetek nagy többségében szintén gondot okoz. Nagyon sok esetben az elkészült, kiváló tananyagok nem tudnak eljutni a potenciális célközönséghez, hiszen a használók nem szereznek róluk tudomást az egységes és központi rendszerbe szervezetlenség miatt.

Bővíti a problémateret, hogy az elektronikus tananyagok előállítása, szolgáltatása, megőrzése kapcsán generálisan és egyértelműen alkalmazható iparági sztenderdek egyelöre még kevéssé kristályosodtak ki. Az e-learning oktatási anyagok és a különféle MOOC-kurzusok dinamikus és interaktív lejátszását lehetővé tevő keretrendszerek évről évre változnak: újak születnek, stabilnak hitt platformok pedig megszünnek. Ebben a folyamatosan változó, kissé kaotikus környezetben a könyvtár lehet az a biztos pont, amely igazi memóriaintézményként viselkedve vezető szerepet játszhat a digitális oktatási anyagok hosszú távú tárolását lehetővé tévő archiválási megoldások kidolgozásában.

A nemzetközi térben OER (Open Educational Resources = nyílt oktatási erőforrások) domain alatt tárgyalódik a téma7, ${ }^{8}, 9$. Az OER rendszerekben általában alkalmazott szabványos metaadatsémák a következők: Dublin Core (DC) és DC Education Application Profile; IEEE Learning Object Metadata (LOM) és IMS Metadata MRI; Learning Resource Metadata Initiative (LRMI) ${ }^{10}$.

$5 \quad$ Bothwell, Ellie. Moocs can transform education - but not yet. (2017), Hozzáférés: 2018.05.30. https://www.timeshighereducation.com/features/massive-open-online-courses-moocs-can-transform-educationbut-not-yet

6 Drótos László. Az internet archiválása mint könyvtári feladat. Tudományos és Müszaki Tájékoztatás, 64. 7-8. sz. (2017), 361-371.

7 Afonso, M. D. C. L., Eirão, T. G., Melo, J. H. M., da Silva Assunção, J., \& Leite, S. V. Banco Internacional de Objetos Educacionais (BIOE): tratamento da informação em um repositório educacional digital. Perspectivas em Ciência da Informação, 16. 3. sz. (2011), 148-158.

8 Atenas, J., \& Havemann, L. Questions of quality in repositories of open educational resources: a literature review. Research in Learning Technology, 22. 1. Sz. (2014), 20889.

9 Santos-Hermosa, G., Ferran-Ferrer, N., \& Abadal, E. Repositories of Open Educational Resources: An Assessment of Reuse and Educational Aspects. The International Review of Research in Open and Distributed Learning, 18. 5. sz. (2017) Hozzáférés: 2018.05.30. Holl András, Köpösdi Zsuzsa és Nagy Gyula. Szakértői vélemény a Digitális Tankönyvtár megújításáról [Kézirat], (2017) 


\section{NETWORKSHOP 2018}

Fontos kiemelnünk ezen rendszerek filozófiai alapját képező tanulási objektum alapú megközelítést. Az egyes erőforrások építőelemekként viselkednek, melyek skálája az egész alacsony szervezettségi szinttől (egy-egy önálló objektum, pl. kép) az egészen magas szervezettségi szintig (pl. több féléves tematikus kurzusanyagokig) tart. Az egyes alacsonyabb szervezettségi szintü objektumok sok esetben valójában építőkövekként szolgálnak egy magasabb szervezettségi szint eléréséhez, cserébe rugalmasan, interoperábilisan, több különbözö tananyagban is felhasználhatóak.

\section{Módszer és eredmények - SZTE Elektronikus Tananyag Archívum}

Az általunk kidolgozott módszer a felsőoktatási- és szakkönyvtárak által közelmúltban kiépített és üzemeltetett, mára széles körben müködő repozitóriumrendszerek esetében alkalmazott megoldások kiterjesztésével kísérli meg az intézményi oktatási anyagok integrálását ennek a speciális dokumentumtípusnak a begyűjtésével, rendszerbe szervezésével, raktározásával és a hosszú távú biztonságos megőrzés céljával. A repozitóriumrendszerek ilyen irányú kiterjesztése valójában adja magát, hiszen azok bármilyen kiterjesztésű fájl tárolására alkalmasak, az állományok tárolása indifferens azok típusától. A repozitóriumok nagyon leegyszerüsítve tulajdonképpen a hagyományos fájlrendszer és könyvtárstruktúra elé szervezett metaadatnyilvántartó rendszerek, azzal a plusz szolgáltatással, hogy amikor a tárolt dokumentumtípus azt lehetővé teszi, akkor megtörténik a teljes szövegű indexelés is a későbbi visszakereshetőség miatt ${ }^{11}$.

Az SZTE Elektronikus Tananyag Archívum létrehozásával elsődleges célunk volt, hogy az egyetemen belül biztosítsuk a közpénzből, munkaidőben vagy pályázati forrásból előállított tananyagok időtálló archiválását. Ne fordulhasson elő az a helyzet, hogy a pályázati fenntartási kötelezettség lejártával az elkészített tananyagok elérése megszűnjön. Az eltűnés réme mellett, válaszolva az elméleti részben kifejtett láthatósági problémákra, további célunk volt egy központi, egységes, átlátható adatbázis építése a mostani széttagoltság helyett. Reményeink szerint ez a transzparencia fokozni fogja az anyagok használati körét, ezáltal jobb hasznosulást biztosítva. A láthatóság további fokozása miatt a könyvtári dokumentumnak minősülő anyagokat a könyvtár online katalógusában is tükröztetni fogjuk, hiszen ez az egyetem elsődleges bibliográfiai adatbázisa.

Az oktatási anyagok repozitálásához az egyetem publikációs repozitóriuma szolgált mintául - az oktatók publikációs munkássága mellett tananyagkészítési munkásságuk archiválása is szükséges, hiszen ez ugyanúgy egyetemi munkásságuk részét képezi. Az oktatók általi egyéni feltöltések mellett biztosítanunk kellett a könyvtári adminisztráció általi tömeges adatfeltöltés lehetőségét is. Az anyagokhoz való hozzáférés a megszokott módon, különböző hozzáférési szintek (szabadon hozzáférhető, egyetemi IP, regisztrált felhasználók, csak az archívum karbantartója, eduID, stb.) mentén történhet.

Az általunk választott és széleskörüen használt Eprints rendszer esetében néhány évvel ezelött elkezdődött egy dedikált, a nyílt oktatási anyagok rugalmas közzétételét lehetővétévő platformkialakítása EdShare márkanév alatt. Ez a rendszer ugyanúgy EPrints alapokon nyugszik, azonban olyan járulékos 
fejlesztéseket tartalmaz, amely megkönnyíti a mindenféle formátumban elérhető oktatási segédanyagok szolgáltatását, böngészőbe ágyazott, dedikált segédprogramok nélküli megjelenítést lehetővé téve, olyan elterjedt fájlformátumok esetében mint a PDF, Word, PowerPoint dokumentumok, videók. Ezek miatt a plusz kényelmi szolgáltatások miatt kézenfekvő választás lett volna részünkről ennek a kiterjesztett rendszernek a használata, de sajnos az EPrints alapváltozatához képest többletfejlesztéseket tartalmazó változat forráskódját a fejlesztők nem tették szabadon elérhetővé. Annak telepítését és kialakítását a nonprofit alapokon nyugvó EPrints Services nevü prémiumszolgáltatásuk keretében pénzért értékesítik, így a szoftver alapváltozatát voltunk kénytelenek használni, az oktatási anyagok tárolásához szükséges testreszabást mi magunk végeztük el.

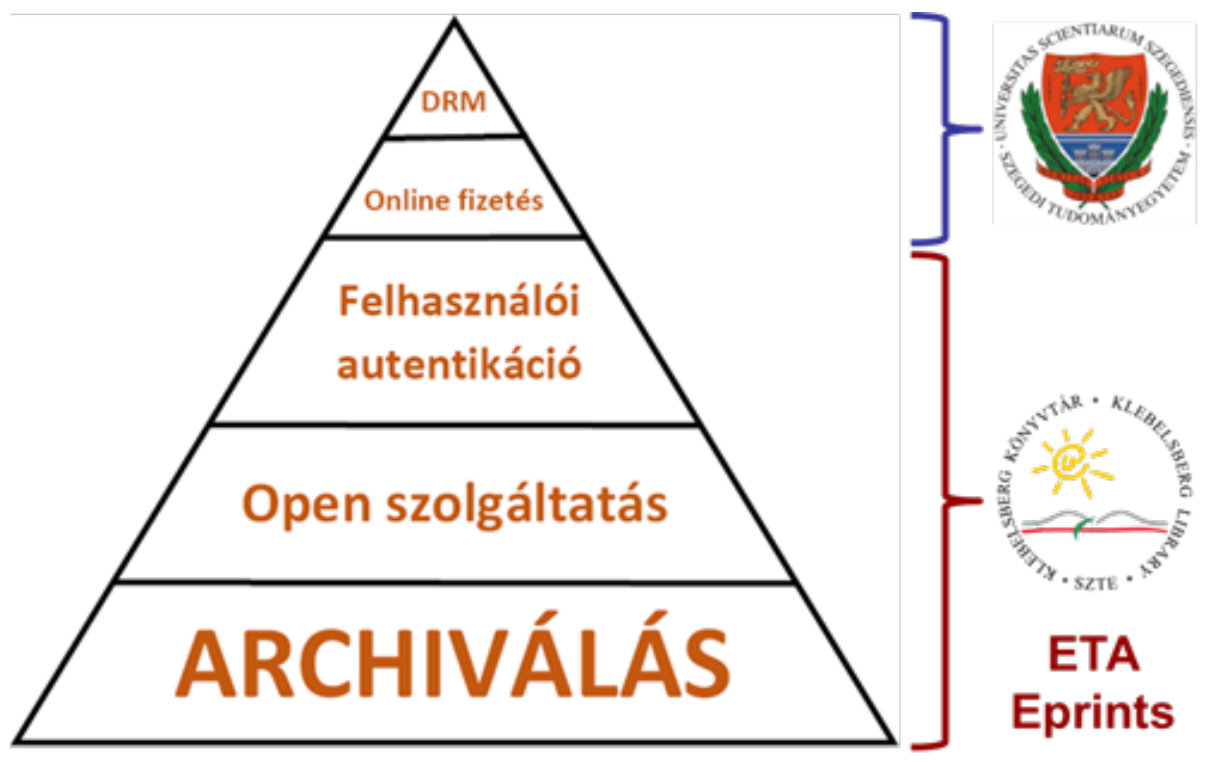

1. ábra Szolgáltatási szintek modellje, rendszeren belül és kívül

A rendszer tervezése és az adatstruktúra létrehozása során fel kellett mérnünk a tipikus elektronikus tananyagtípusokat, fájlformátumokat, a tananyagok általános szervezettségi szintjeit és az oktatási anyagokra jellemző speciális adatelemeket. Ezeket az alábbiakban közöljük.

\subsection{Azonosított tananyagtípusok:}

- Online oktatási csomag (e-learning lecke/téma)

E-learning és MOOC keretrendszerekböl archivált oktatási csomag.

\section{- Jegyzet, tankönyv}

Oktatási célú, könyvjellegü dokumentum.

\section{- Prezentáció}

Tanulást segítő prezentációk és az előadások anyagát tartalmazó diasorok.

- Kép

Oktatási témájú képi tartalom.

\section{- Videóanyag}

Oktatóvideók és előadások felvételei. 


\section{NETWORKSHOP 2018}

\section{- Hanganyag}

Oktatási témájú audiofájlok és előadások hangfelvételei.

\section{- Útmutató}

Tájékoztató anyagok, tanmenetek, leírások.

- Tanítási erőforrások, tanulási objektumok

Tanulást segítő dokumentumok: feljegyzések előadásokról, handoutok, kötelező olvasmányok, gyakorlófeladatok, tesztek, vizsgakérdések.

- Egyéb

Egyéb, digitális oktatási anyagok, melyek nem sorolhatóak be a fenti kategóriák egyikébe sem.

\subsection{Legsürübben előforduló fájltípusok:}

- PDF, PPT, ePub, docx, HTML, SCORM, videó- és audiofájlok, stb.

Igazából bármilyen formátumot tud kezelni a rendszer, viszont lehetőség szerint olyan formátumot javasolunk, amit natívan támogatnak a modern webböngészők (pl. PDF vagy HTML).

\subsection{Tananyagok szervezettségi szintje:}

Mekkora tananyagegységről van szó? A lehetséges opciók a több félévet átölelő képzési anyagoktól kezdve az elemi tanulási objektumokig (pl. egy-egy kép, grafikon, stb.) terjednek.

- önálló tanulási objektum

- önálló dokumentum

- önálló téma, tanóra

- önálló tantárgy, kurzus

- önálló képzési blokk

\subsection{Oktatási anyagokra jellemző speciális adatelemek:}

- Lejátszáshoz szükséges keretrendszer

Csomag implementálásához szükséges keretrendszer. Pl. Moodle, CooSpace, Webuni, eXeLearning, stb.

\section{- Nehézségi szint}

A tananyag elsajátításának nehézségi foka: 1 - nagyon könnyü; 5 - nagyon nehéz.

\section{- Tipikus tanulási idő}

Az optimális időtartam, ami alatt a hallgató a tananyagot várhatóan elsajátítja. Pl. 2 nap; 3 óra; 4 hét.

- Célcsoport

A megcélzott felhasználói kör, akinek a tananyagot elsősorban készítették. Pl. első éves mesterszakos közgazdászok; angol nyelvű orvosi képzésben résztvevők, stb.

\section{- Feladatcél}

A tananyag elsajátítása során megszerzett ismeretek optimális kimenete. Pl. Past Perfect ismerete; alapvető anatómiai ismeretek, stb.

\section{- Készségterületek}

A tananyag elsajátításához esetlegesen szükséges elő- és részismeretek halmaza. Pl. C++ programnyelv; SQL. 


\section{- Szemeszter}

Az egyetemi félév jelölése, amelyre a tananyag vonatkozik. Pl.: 2017/18/2.

\section{- Kurzuskód}

A tananyaghoz tartozó kurzus kódja. A „További sorok”-ra kattintva többet is megadhat.

PI. INFKo9_A011.

2.5 Általános müködési modell:

\section{Oktató feltölti a tananyagot}

2. Jogosítási jóváhagyás

3. Tartalmi jóváhagyás

4. Könyvtári jóváhagyás

5. Élö archívum $\odot$

2. ábra Az ETA repozitórium általános munkafolyamat-sémája 